\title{
Purification and characterization of an antimicrobial protein from Gastrodia elata Blume tubers
}

\author{
Chen Chen ${ }^{1,2}$, Xinxin $\mathrm{Li}^{1,2}$, Jing $\mathrm{Li}^{1,2}$, Youmei $\mathrm{Xu}^{1,2}$, Xian Jing ${ }^{1}$, Sanqiao $\mathrm{Wu}^{1}$, \\ Xiang Liu ${ }^{1,2 \star}$, Xiaoying Zhang ${ }^{1,3 \star}$ \\ ${ }^{1}$ Chinese-German Joint Laboratory for Natural Product Research, Qinling-Bashan Mountains Bioresources Comprehensive \\ Development CIC, College of Biological Science and Engineering, Shaanxi University of Technology, Hanzhong 723001, \\ ${ }^{2}$ Shaanxi Engineering Research Center of Tall Gastrodia Tuber and Medical Dogwood, Hanzhong 723001, ${ }^{3}$ College of \\ Veterinary Medicine, Northwest A\&F University, Yangling 712100, China
}

*For correspondence: Email: zhang.xy@nwsuaf.edu.cn, liuxiang888525@163.com; Tel/Fax: +86-0916-2641661

\begin{abstract}
Purpose: To purify and characterize a novel antimicrobial protein from the Gastrodia elata Blume (BI.) plant, which has long been used in herbal medicine.

Methods: The procedure for isolation and purification of Gastrodia elata protein (GEP) involved phosphate buffer extraction, ammonium sulfate precipitation, ion-exchange chromatography, and gelfiltration chromatography. Sodium dodecyl sulfate - polyacrylamide gel electrophoresis was employed to detect the apparent molecular mass and determine homogeneity, while paper disc diffusion was used to measure the antibacterial activity of GEP. A hemolytic assay was performed on rabbit red blood cells. The effect of $\mathrm{pH}$, salt concentration, and temperature on the antibacterial activity of GEP was evaluated by minimum inhibitory concentration assay.

Results: GEP was a 14-kDa monomer and displayed antimicrobial activity against Staphylococcus aureus and Candida albicans, with 8.0- $\mathrm{mm}$ and 9.4-mm zones of inhibition, respectively, but no antibacterial activity was observed against Escherichia coli. GEP had little hemolytic activity on red blood cells even at a concentrations of up to $200 \mathrm{mg} / \mathrm{ml}$. GEP was thermally stable at temperatures below $70{ }^{\circ} \mathrm{C}$ for $30 \mathrm{~min}$, and displayed higher antibacterial activity in the $\mathrm{pH}$ range 5.0 to 7.0.

Conclusion: GEP protein is relatively thermostable and possesses antimicrobial activity. The results suggest that GEP protein has potential agricultural and industrial applications, such as in transgenic plants.
\end{abstract}

Keywords: Antimicrobial protein, Gastrodia elata, Protein characterization

\begin{abstract}
This is an Open Access article that uses a funding model which does not charge readers or their institutions for access and distributed under the terms of the Creative Commons Attribution License (http://creativecommons.org/licenses/by/4.0) and the Budapest Open Access Initiative (http://www.budapestopenaccessinitiative.org/read), which permit unrestricted use, distribution, and reproduction in any medium, provided the original work is properly credited.

Tropical Journal of Pharmaceutical Research is indexed by Science Citation Index (SciSearch), Scopus, International Pharmaceutical Abstract, Chemical Abstracts, Embase, Index Copernicus, EBSCO, African Index Medicus, JournalSeek, Journal Citation Reports/Science Edition, Directory of Open Access Journals (DOAJ), African Journal Online, Bioline International, Open-J-Gate and Pharmacy Abstracts
\end{abstract}

\section{INTRODUCTION}

Plants exhibit a variety of defenses to combat bacteria in the environment. Despite not having an integrated immune system, plants produce proteins and peptides with antibacterial activity to combat pathogenic invasion [1]. Transgenic plants that express antibacterial proteins are expected to be resistant to bacterial infections. Therefore, several investigators have identified and characterized the antibacterial properties of proteins and peptides derived from the leaves, 
flowers, seeds, roots, and stems of plants [2,3] These proteins and peptides display antibacterial activity against phytopathogens, as well as bacteria that are pathogenic to humans. Thus, plant-derived antibacterial proteins and peptides are considered promising antibiotic compounds.

Gastrodiae Rhizoma (Chinese name: Tian-ma) is the dried tuber of the Gastrodia elata BI. plant, which is a member of the Orchidaceae family [4]. Gastrodia elata Bl. has been used in herbal medicine for over 2,000 years in many countries, including China, Japan, Korea, and India [5], as a traditional medicine for the treatment of headaches, dizziness, migraine, rheumatism, epilepsy, and nervous disorders [6]. Additionally, Gastrodia elata Bl. has also been used in food, health tea, and as a food additive. The biological functions of its chemical constituents, including gastrodin [7], polysaccharide [8], and lectin, have been reported.

However, whether Gastrodia elata BI. protein extracts possess antibacterial properties are obscure.

\section{EXPERIMENTAL}

\section{Materials}

Fresh Gastrodia elata BI. tubers were purchased from Lueyang County, Shaanxi province, China, and stored at $-20^{\circ} \mathrm{C}$. Lueyang County has been a major area for Gastrodia elata BI. cultivation for over 50 years.

\section{Chemicals and reagents}

Diethylaminoethyl (DEAE)-52 cellulose and Sephadex G-50 were purchased from GE Healthcare Company (Gothenburg, Sweden). The molecular mass marker was purchased from Sangon Biotech Co., Ltd (Shanghai, China). N, $\mathrm{N}, \mathrm{N}, \mathrm{N}$-tetramethyl-ethylenediamine (TEMED) was purchased from Sigma-Aldrich (Saint Louis, Missouri, USA).

\section{Crude extract preparation}

Fresh Gastrodia elata BI. tubers were thoroughly cleaned with tap water and peeled. The tubers were then homogenized at $4^{\circ} \mathrm{C}$ for $2 \mathrm{~min}$ in two volumes of $0.05 \mathrm{~mol} / \mathrm{L}$ phosphate buffer $(\mathrm{pH} \mathrm{7.0)}$, stirred at $4^{\circ} \mathrm{C}$ overnight, filtered through a cheesecloth, and centrifuged at 5000 rpm for 20 min. The supernatant was collected and concentrated by freeze-drying to yield the crude extract of Gastrodia elata Bl. tubers for further purification.

\section{Ammonium sulfate precipitation}

The supernatant was subjected to precipitation using $40-80 \%$ saturated ammonium sulfate at $4^{\circ} \mathrm{C}$, and the supernatant was discarded, while the precipitate was harvested by centrifugation at $5000 \mathrm{rpm}$ for $20 \mathrm{~min}$. The precipitate containing the protein fraction was resuspended in phosphate-buffered saline (PBS) buffer and dialyzed extensively in distilled water for $48 \mathrm{~h}$ to remove ammonium sulfate. The antibacterial activity of each fraction was determined using indicator bacteria.

\section{Primary purification by ion-exchange chroma- tography}

The dialysate was filtered through $0.45-\mu \mathrm{m}$ filters and loaded onto a $1.6 \times 20 \mathrm{~cm}$ DEAE-cellulose anion-exchange column equilibrated with 50 $\mathrm{mmol} / \mathrm{L}$ Tris- $\mathrm{HCl}(\mathrm{pH}$ 7). The column was then washed with the same buffer to remove unbound proteins. Adsorbed proteins were desorbed using stepwise elution with increasing sodium chloride $(\mathrm{NaCl})$ concentrations of $0.1,0.2,0.4$, and 0.6 $\mathrm{mol} / \mathrm{L}$. The flow rate was $0.5 \mathrm{~mL} / \mathrm{min}$ and the eluate was monitored at $280 \mathrm{~nm}$. Elution fractions were pooled, concentrated, and dialyzed overnight with distilled water. The buffer used for dialysis was changed two to three times to ensure the complete removal of salts. The antibacterial activity of each fraction was also determined. The first fraction (D1) demonstrating antibacterial activity was lyophilized and stored at $-4^{\circ} \mathrm{C}$ for further purification.

\section{Secondary purification by gel-filtration chromatography}

The lyophilized fraction from the anion-exchange column was resuspended in ultrapure water, centrifuged at 10,000 rpm for $10 \mathrm{~min}$, and filtered through a $0.45-\mu \mathrm{m}$ filter prior to chromatography. The sample was added to a gel-filtration chromatograph using Sephadex G-50 beads preequilibrated with $100 \mathrm{mmol} / \mathrm{L}$ PBS solution $(\mathrm{pH}$ 7). Then, elution was performed with PBS at a regulated flow rate of $30 \mathrm{~mL} / \mathrm{h}$ into $6 \mathrm{~mL}$ collection tubes. The absorbance of the eluate was detected at $280 \mathrm{~nm}$, and the active components were lyophilized.

\section{Concentration measurement and homoge- neity analysis of the purified protein}

During the purification process, protein concentrations were measured by the Bradford method using a Coomassie Protein Assay Kit from Applygen Technologies Inc. (Beijing, China). Bovine serum albumin was used as the 
standard. Sodium dodecyl sulfate polyacrylamide gel electrophoresis (SDS-PAGE) electrophoresis was used to detect the apparent molecular mass and homogeneity of the purified antibacterial proteins. All samples were heated for $5 \mathrm{~min}$ in boiling water prior to SDS-PAGE. The protein bands were visualized by staining with R-250.

\section{Antibacterial activity determination}

Paper disc diffusion was utilized to detect the antibacterial activity of the crude extract, ionexchange chromatography fractions, and gelfiltration chromatography fractions [9]. A suspension of each indicator strain $\left(10^{7} \mathrm{CFU} / \mathrm{mL}\right)$ was spread on LB agar plates $(\Phi=90 \mathrm{~mm})$. Four paper discs $(\Phi=6 \mathrm{~mm})$ were placed in each agar plate using sterile forceps. Each protein sample $(30 \mathrm{mg} / \mathrm{mL})$ was transferred at $6 \mu \mathrm{L} /$ well, and sterile water was used as negative control. All bacterial plates were incubated for $12 \mathrm{~h}$ at $37^{\circ} \mathrm{C}$. The diameter of the minimum zone of inhibition was measured in millimeters. The test strains were Escherichia coli (ATCC25922), Staphylococcus aureus (ATCC25923), and Candida albicans (ATCC2002).

The minimum inhibitory concentration (MIC) of the antibacterial protein-of-interest was detected using microdilution methods [10] with an initial strain concentration of $5 \times 10^{5} \mathrm{CFU} / \mathrm{mL}$. The antibacterial activity was examined in sterile 96well plates at final volumes of $100 \mu \mathrm{L}, 90 \mu \mathrm{L}$, and $10 \mu \mathrm{L}$ of the antibacterial protein. The purified protein $(50 \mu \mathrm{L})$ was added to the 96 -well culture plates along with LB medium. A total of $50 \mu \mathrm{L}$ of bacteria $\left(5 \times 10^{5} \mathrm{CFU} / \mathrm{mL}\right)$ was added to each well, and incubated at $37^{\circ} \mathrm{C}$ for $24 \mathrm{~h}$. Bacterial growth was detected by absorbance at $600 \mathrm{~nm}$. MIC was calculated as the lowest protein concentration that reduced bacteria growth by $50 \%$ relative to the control. All experiments were performed in duplicate with three replicates each.

\section{Hemolytic assay}

Hemolytic assay was performed using rabbit red blood cells [11]. Briefly, fresh rabbit red blood cells were washed with $0.85 \%$ saline, limiting the final concentration to $2 \%(\mathrm{v} / \mathrm{v})$. The antibacterial protein was added in serial dilution, and incubated for $30 \mathrm{~min}$ at $37^{\circ} \mathrm{C}$. After centrifugation, absorbance of the supernatant was detected. The control experiment for maximum hemolysis was performed by adding $1 \%$ Triton X-100 to the red blood cells. The hemolytic assay was repeated three times.

\section{Effect of pH, salt concentration, and temperature}

The effect of $\mathrm{pH}$ on the antibacterial activity of the protein was measured in the $\mathrm{pH}$ range of 5 to 10. MIC was used to determine antibacterial activity at different $\mathrm{pH}$ values after incubating at room temperature for $30 \mathrm{~min}$.

The effect of salt concentration on the antimicrobial activity of the protein was detected by evaluating the MIC at different concentrations. $\mathrm{NaCl}$ at varying concentrations (from 0-300 $\mathrm{mmol} / \mathrm{L}$ ) was added to the Mueller-Hinton broth used in the assay.

The thermal stability of the protein was tested by heating the protein to temperatures ranging from 30 to $90{ }^{\circ} \mathrm{C}$ for $30 \mathrm{~min}$. After cooling to room temperature, the MIC of the protein was measured as described above. The test was repeated three times.

\section{RESULTS}

\section{Purification of the antibacterial protein}

The protein was purified from Gastrodia elata BI. tubers using ammonium sulfate precipitation, ionexchange chromatography using DEAE-52 columns, and gel-filtration chromatography using Sephadex G-50 columns (Table 1). The protein yield was $9.33 \%$; i.e., the yield from $100 \mathrm{~g}$ of fresh Gastrodia elata Bl. tubers after multiple steps of purification was $9.33 \mathrm{~g}$ of protein. The crude extract was precipitated with ammonium sulfate $(40,50,60,70$, and $80 \%$ saturation). The results indicated that $80 \%$ saturation achieved the highest yield of crude extract, i.e., $40.77 \%$. The $80 \%$ ammonium sulfate fraction was separated into four fractions using DEAEcellulose, as indicated in Figure 1A. The D1 fraction contained the active protein, and this was further purified on a Sephadex G-50 gelfiltration column. The D1 fraction was further divided into three fractions (G1, G2, and G3) on a Sephadex G-50 gel-filtration column. Only the G3 fraction exhibited antibacterial activity (Figure 1B). The isolated protein was demonstrated to be a $14 \mathrm{kDa}$ monomer by SDS-PAGE analysis (Figure 2).

\section{Antimicrobial activity}

The antibacterial activity of the protein (GEP) purified from Gastrodia elata Bl. tubers was examined by paper disc diffusion against the three indicator strains shown in Table 3 . The crude extract, ion-exchange fractions, and gelfiltration chromatography fractions displayed 
clear antibacterial activity against $C$. albicans ATCC 2002, and moderate activity against $S$. aureus ATCC 25923. However, they did not exhibit antibacterial activity against $E$. coli ATCC 25922.

Table 1: Purification of the antibacterial protein from $500 \mathrm{~g}$ fresh Gastrodia elata Bl tubers

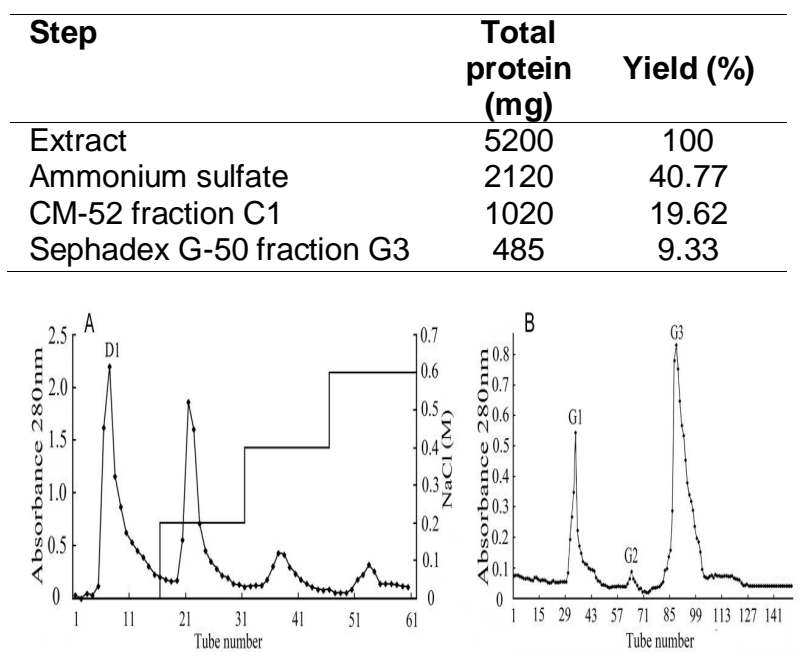

Figure 1: Column chromatography purification of antibacterial protein from Gastrodia elata BI. tubers. A lon-exchange chromatography on DEAE-cellulose. B. Gel-filtration on Sephadex G-50

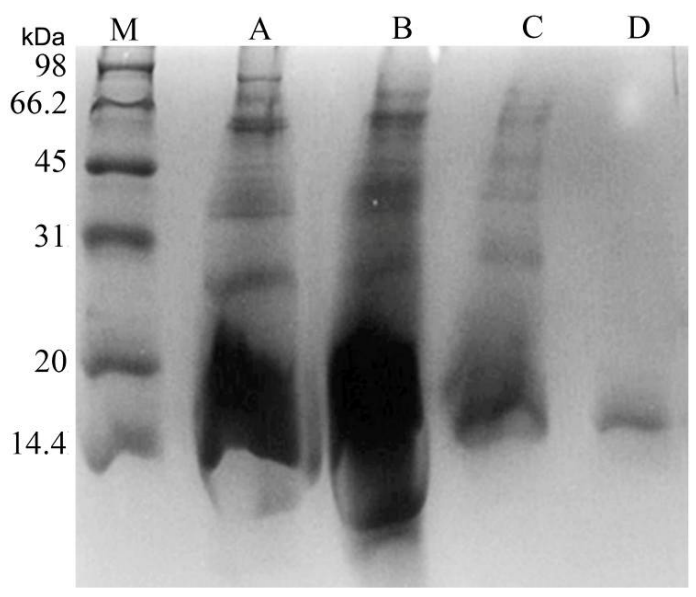

Figure 2: SDS-PAGE analysis of antibacterial protein during successive purification steps. $M$, protein marker. A, crude extract of Gastrodia elata BI tubers. $B$, dialyzed proteins (precipitated by ammonium sulfate). C, purified proteins after chromatography on DEAE-52 (ion-exchange). D, purified protein after chromatography on Sephadex G-50 (gel-filtration)

\section{Hemolytic activity}

The purified antibacterial protein obtained from Gastrodia elata BI. displayed moderate hemolytic activity. Compared with the control $-1 \%$ Triton X-100 - which can induce $100 \%$ hemolysis, the antibacterial protein obtained from Gastrodia elata $\mathrm{Bl}$. resulted only in $4 \%$ hemolysis even at the high concentration of $200 \mathrm{mg} / \mathrm{mL}$. Thus, the GEP protein may show potential as a novel antimicrobial drug that is safe to use in animals.

Table 3: Antibacterial activity of antibacterial protein from Gastrodia elata $\mathrm{Bl}$ tubers against indicator strains

\begin{tabular}{lccc}
\multirow{2}{*}{$\begin{array}{l}\text { Test } \\
\text { material }\end{array}$} & \multicolumn{3}{c}{$\begin{array}{c}\text { Zone of inhibition (mm; mean } \pm \text { SD; } \\
\mathbf{n}=3 \text { ) }\end{array}$} \\
\cline { 2 - 4 } & E. coli & S. aureus & C. albicans \\
Water & - & - & - \\
Extract & - & $6.0 \pm 0.10$ & $7.5 \pm 0.31$ \\
D1 & - & $7.2 \pm 0.27$ & $9.0 \pm 0.41$ \\
G3 & - & $8.0 \pm 0.36$ & $9.4 \pm 0.29$ \\
\hline - = indicates no detectable zone of inhibition
\end{tabular}

\section{Effect of $\mathrm{pH}$, salt, and temperature}

To determine the optimal $\mathrm{pH}$ range for the antimicrobial activity of the protein of interest, the MIC of the GEP protein against $S$. aureus and $C$. albicans was determined at a range of $\mathrm{pH}$ values. Different $\mathrm{pH}$ conditions had profound effects on the antibacterial activity of the GEP protein. The MIC was greater in alkaline conditions than in acidic conditions, and the antibacterial activity was determined to be optimal at pH 6 (Figure 3).

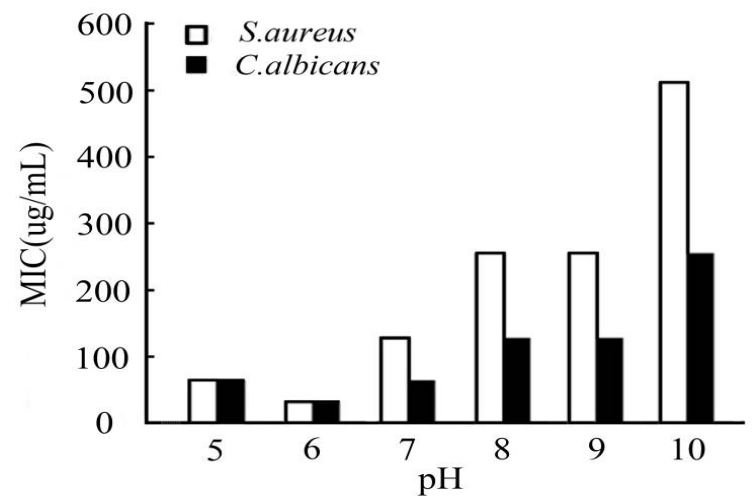

Figure 3: Effect of $\mathrm{pH}$ on the MIC of the purified protein against $S$. aureus and $C$. albicans

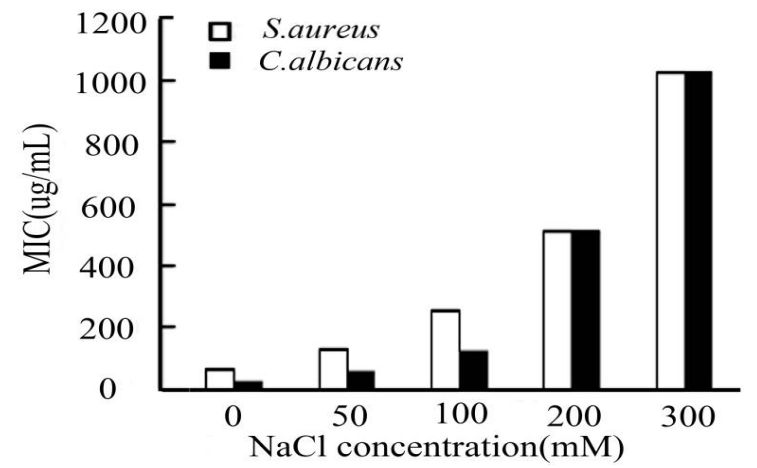

Figure 4: Effect of $\mathrm{NaCl}$ concentration on the MIC of the purified protein against $S$. aureus and $C$. albicans 


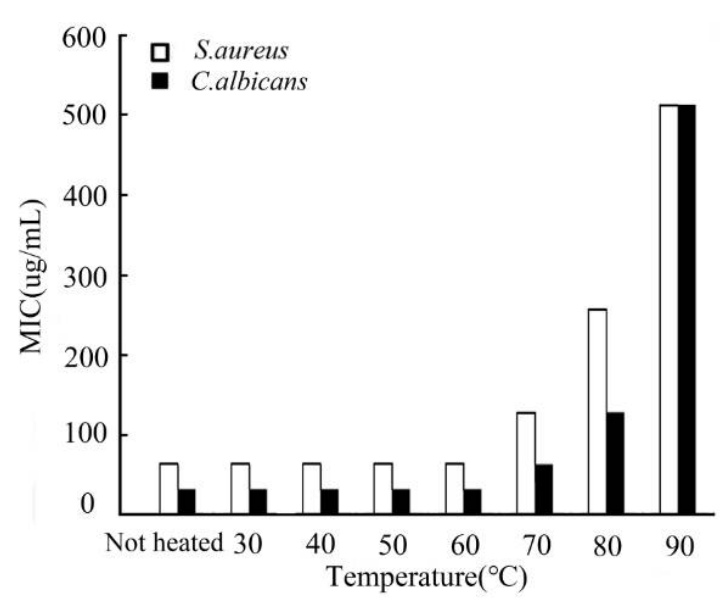

Figure 5: Effect of temperature on the MIC of the purified protein against $S$. aureus and $C$. albicans

The salt sensitivity of the protein was established by detecting the MIC of the protein against $S$. aureus and $C$. albicans in the presence of $\mathrm{NaCl}$ concentrations from 0 to $300 \mathrm{mmol} / \mathrm{L}$. The $\mathrm{MIC}$ of the GEP protein was inhibited at high ionic concentrations of salt (Figure 4).

To investigate the thermal stability of the protein of interest, the antibacterial protein was exposed to different temperatures for $30 \mathrm{~min}$ (Figure 5). GEP retained high levels of antibacterial activity after incubation at $30,40,50$, or $60^{\circ} \mathrm{C}$ for $30 \mathrm{~min}$ as assessed by the MIC assay against $S$. aureus and C. albicans. Importantly, the antibacterial protein exhibited a 16-fold increase in MIC against $S$. aureus and an 8-fold increase in MIC against $C$. albicans on heating to $90^{\circ} \mathrm{C}$ for 30 min, when compared to an unheated control.

\section{DISCUSSION}

A Gastrodia elata antibacterial protein was successfully isolated using a procedure that has proven useful for its purification. The methods used here include ammonium sulfate precipitation, ion exchange chromatography, gel filtration chromatography, preparative liquid chromatography, affinity chromatography and combined chromatography techniques, all of which have previously been used for the isolation and purification of antibacterial peptides/proteins from plants [12]. Lam et al purified an antifungal protein from mushroom (Lyophyllum shimeji) using ammonium acetate extraction, $\mathrm{CM}-$ cellulose ion exchange chromatography, Affi-Gel blue gel affinity chromatography, and Mono $S$ high performance liquid chromatography [13]. Boleti et al purified a $14-\mathrm{kDa}$ antifungal protein from Pouteria torta seeds using Sephacryl S-100 size exclusion chromatography, DEAESepharose ion exchange chromatography, and C18 reverse-phase HPLC [14]. Ruan et al. reported purifying an antifungal protein with a molecular mass of $14 \mathrm{kDa}$ from Fagopyrum tataricum seeds using ammonium sulfate precipitation, affinity chromatography, and centrifugal ultrafiltration [15].

The antibacterial protein isolated from Gastrodia elata Blume tubers in the present study has a molecular weight of $14 \mathrm{kDa}$, similar to that of antibacterial proteins previously isolated from other plant-derived materials. An antifungal protein isolated from the mushroom Lyophyllum shimeji exhibited a molecular mass of $14 \mathrm{kDa}$ [13]. Antifungal proteins from Pouteria torta seed and Fagopyrum tataricum seed each have a molecular mass of $14 \mathrm{kDa}[14,15]$. Pr-2, an antifungal protein from pumpkin rind has a molecular mass of $14.8 \mathrm{kDa}$ [16].

Many plant-derived proteins have been shown to display antibacterial activity against phytopathogens and against organisms that are pathogenic to animals and humans, including bacteria, viruses, fungi, parasites, and neoplastic cells [17]. In the present study, the GEP displayed significant antibacterial activity against fungi, and moderate activity against grampositive bacteria. However, they did not exhibit antibacterial activity against gram-negative bacteria. Interestingly, the results are consistent with those reported for an antifungal protein purified from the Ginkgo biloba seed.

Some studies have confirmed that antibacterial proteins from plant seeds, fungi, and bacteria exhibit significant hemolytic activity, and are therefore harmful to erythrocytes [18]. However, GEP had little hemolytic activity on rabbit red blood cells even at protein concentrations up to $200 \mathrm{mg} / \mathrm{ml}$.

Our research showed that the GEP protein retains significant antibacterial activity at $\mathrm{pH}$ values up to 10.0 , and displays good thermal stability up to $60^{\circ} \mathrm{C}$. However, Sakthivel et al [12] purified an antibacterial protein from Bauhinia purpurea L., which had no antibacterial activity at $\mathrm{pH}$ values below 3.0 and above 9.0. Zheng et al. [2] found that an antibacterial protein from Clitocybe sinopica had no activity at temperatures above $80^{\circ} \mathrm{C}$.

Some antibacterial proteins lose their antibacterial activity at high salt concentrations. This is in accordance with previous studies, which found that the antibacterial activity of such proteins is greatly influenced by salt concentration, and no antibacterial activity was observed under high salt concentrations. 


\section{CONCLUSION}

A novel antibacterial $14-\mathrm{kDa}$ GEP protein has successfully been purified from Gastrodia elata Bl tubers. GEP exhibits antimicrobial activity against $S$. aureus and $C$. albicans, but has no antibacterial activity against $E$. coli. The protein is thermally stable and displays potent antibacterial activity under acidic conditions. Thus, the GEP protein derived from Gastrodia elata Bl. tubers is a potential candidate for further drug development.

\section{DECLARATIONS}

\section{Acknowledgement}

This work was supported by High-end Foreign Experts Recruitment Program of State Administration of Foreign Experts Affairs (nos. GDT20176100048 and GDT20186100426); Shaanxi Provincial Science and Technology Coordinating Innovative Engineering Project (nos. 2015KTTSSF01-03 and 2015HBGC-18); Shaanxi Provincial Science and Technology Research Development Program (nos. 2017NY180 and 2016XT-13), Research Project of Shaanxi Provincial Education Department (17JK0135), and Qinling Bashan Mountains Bioresources Comprehensive Development and Collaborative Innovation (no. QBXT-Z(Z)-15-21).

\section{Conflict of Interest}

No conflict of interest associated with this work.

\section{Contribution of Authors}

The authors declare that this work was done by the authors named in this article and all liabilities pertaining to claims relating to the content of this article will be borne by them.

\section{REFERENCES}

1. Escudero V, Jordá L, Sopeña-Torres $S$, Mélida $H$, Miedes E, Muñoz-Barrios A, Swami S, Alexander D, McKee LS, Sánchez-Vallet $A$, et al. Alteration of cell wall xylan acetylation triggers defense responses that counterbalance the immune deficiencies of plants impaired in the $\beta$-subunit of the heterotrimeric G-protein. Plant J 2017; 92(3): 386-399.

2. Zheng $S$, Liu $Q$, Zhang $G$, Wang $H, N g$ TB. Purification and characterization of an antibacterial protein from dried fruiting bodies of the wild mushroom Clitocybe sinopica. Acta Biochim Pol 2010; 57(1): 43-48.
3. Hong J, Chen TT, Hu P, Wang SY. A novel antibacterial tripeptide from Chinese leek seeds. Eur Food Res Technol 2015; 240(2): 327-333.

4. Liu ZK, Ng CF, Shiu HT, Wong HL, Wong CW, Li KK, Zhang JF, Lam PK, Poon WS, Lau CB, Leung PC, Ko $\mathrm{CH}$. A traditional Chinese formula composed of Chuanxiong Rhizoma and Gastrodiae Rhizoma (Da Chuanxiong Formula) suppresses inflammatory response in LPS -induced RAW 264.7 cells through inhibition of NF-KB pathway. J Ethnopharmacol 2017; 196: 20-28.

5. Matias M, Silvestre S, Falcao A, Alves G. Gastrodia elata and epilepsy: Rationale and therapeutic potential. Phytomed 2016; 23(12): 1511-1526.

6. Zhan HD, Zhou HY, Sui YP, Du X L, Wang WH, Dai L, Sui $F$, Huo HR, Jiang TL. The rhizome of Gastrodia elata Blume-An ethnopharmacological review. J Ethnopharmacol 2016; 189: 361-385.

7. Wang $P H$, Zhao LX, Wan JY, Zhang L, Mao XN, Long $F Y$, Zhang S, Chen C, Du JR. Pharmacological characterization of a novel gastrodin derivative as a potential anti-migraine agent. Fitoterapia 2016; 109: 5257.

8. Chen X, Cao DX, Zhou L, Jin HY, Dong Q, Yao J, Ding K. Structure of a polysaccharide from Gastrodia elata BI., and oligosaccharides prepared thereof with antipancreatic cancer cell growth activities. Carbohyd Polym 2011; 86(3): 1300-1305.

9. Gefen O, Cheko B, Strahilevitz J, Balaban NQ. TDtest: easy detection of bacterial tolerance and persistence in clinical isolates by a modified disk-diffusion assay. Scientific Reports 2017; 7: 41284.

10. Wiegand I, Hilpert K, Hancock RE. Agar and broth dilution methods to determine the minimal inhibitory concentration (MIC) of antimicrobial substances. Nat Protoc 2008; 3(2): 163-175.

11. Puissant-Lubrano B, Puissochet $S$, Congy-Jolivet $N$, Chauveau D, Decramer S, Garnier A, Huart A, Kamar N, Ribes $D$, Blancher A. Alternative complement pathway hemolytic assays reveal incomplete complement blockade in patients treated with eculizumab. Clin Immunol 2017; 183: 1-7.

12. Sakthivel $M$, Palani $P$. Isolation, purification and characterization of antimicrobial protein from seedlings of Bauhinia purpurea L. Int J Biol Macromol, 2016, 86:390-401.

13. Lam SK, Ng TB. First simultaneous isolation of a ribosome inactivating protein and an antifungal protein from a mushroom (Lyophyllum shimeji) together with evidence for synergism of their antifungal effects. Arch Biochem Biophys 2001; 393(2): 271-280.

14. Boleti AP, Freire Md, Coelho MB, Silva Wd, Baldasso PA, Gomes VM, Marangoni S, Novello JC, Macedo ML. Insecticidal and antifungal activity of a protein from Pouteria torta seeds with lectin-like properties. J Agric Food Chem 2007; 55(7):2653-2658. 
15. Ruan JJ, Chen $H$, Shao JR, Wu Q, Han XY. An antifungal peptide from Fagopyrum tataricum seeds. Peptides 2011; 32(6):1151-1158.

16. Park SC, Kim JY, Lee JK, Hwang I, Cheong H, Nah JW, Hahm KS, Park Y. Antifungal mechanism of a novel antifungal protein from pumpkin rinds against various fungal pathogens. J Agric Food Chem 2009; 57(19): 9299-9304.
17. Tam JP, Wang S, Wong KH, Tan WL. Antimicrobial peptides from plants. Pharmaceuticals 2015; 8(4): 711757.

18. Banerjee G, Nandi A, Ray AK. Assessment of hemolytic activity, enzyme production and bacteriocin characterization of Bacillus subtilis $L R 1$ isolated from the gastrointestinal tract of fish. Arch Microbiol 2017; 199(1): 115-124. 